Tropical Journal of Pharmaceutical Research, June 2002; 1 (1): 23-28

(C) Pharmacotherapy Group, Faculty of Pharmacy, University of Benin, Benin City, Nigeria. All rights reserved.

Available online at http://www.tjpr.freehosting.net

Research Article

\title{
Aspects of microbial contamination of tablets dispensed in hospitals and community pharmacies in Benin City, Nigeria
}

\author{
John O. Akerele ${ }^{\dagger}$ and Godwin C. Ukoh
}

Department of Pharmaceutical Microbiology, University of Benin, P.M.B. 1154, Benin City, Nigeria.

\begin{abstract}
Purpose: A research was carried out to investigate the incidence of microflora in tablets dispensed from large container packages used in hospitals and community pharmacies. It was designed to provide baseline data on the common biodegrading microorganisms associated with tablets in retail containers and to highlight the health implications of such observations and roles for pharmacists in self medication phenomenon in Nigeria.

Methods: The protocol for the study involved structured selection of representative named tablets from some public hospitals and community pharmacies within Benin metropolis. Constitutive microorganisms were elaborated and enumerated using standard microbiological protocols.

Results: Our results showed that all the tablets sampled had some form of microbial growth. However, aerobic mesophilic bacteria and fungi observed were within standard numerical limits. It was additionally observed that ascorbic acid and folic acid tablets, particularly from the community pharmacies failed the exclusive criteria for Enterobactereacea and Staphylococci. Tablets from public hospitals in general have lower incidence of exclusive microbial contamination, compared with community pharmacies.

Conclusion: Tablets packed in large containers in retail pharmacies in Benin City are often contaminated with microbial growth. This has possible adverse consequences for those who obtain drugs stored in large containers.
\end{abstract}

Keywords: $\quad$ Microflora, tablets, retail packs, hospitals, community pharmacies.

†Towhom correspondence should be addressed. E-mail: akerelej@uniben.edu 


\section{JO Akerele \& GC Ukoh}

\section{Introduction}

The microbial quality of pharmaceuticals is influenced by the environment and quality of the raw materials used during formulation. Some infectious outbreaks have been associated with the use of heavily contaminated raw materials of natural origin ${ }^{1}$. The incidence of microflora in non-sterile medicines generally is indicated by the nature of the ingredients (whether natural or synthetic), the quality of the vehicle and the care and attitude of personnel involved in their handling ${ }^{2}$.

Most raw materials for pharmaceutical products support some form of microbial growth, depending on the nutritive properties and moisture contents. Hence, dry powder or tablets are capable of undergoing some form of microbial spoilage or degradation. The more serious problem of microbial contamination of tablets is where there is no obvious signs of spoilage, hence it is usually advisable to have knowledge of the microbial content of all drugs and medicines, whether they are required to be sterile or non-sterile ${ }^{2}$. Manufacturing process for tablets reduces the viability of microbial cells significantly, hence microbial growth is rarely observed ${ }^{3}$.

In tropical countries, pharmaceutical preparations are frequently stored under uncontrolled conditions and may be dispensed in non-protective packaging or even without any packaging at all, where the average temperature is $31^{\circ} \mathrm{C}$ and the average relative humidity, $75 \%^{4,5}$. Dispensing of tablets and capsules from large packs is a common practice in hospital pharmacies, clinics, nursing homes, patent medicine stores. Some of these packs take an average of 3 4 weeks to dispense, depending on the demands. In some cases they would take up to six weeks for such packages like ferrous salts, folic acid and vitamin B complex. A study had investigated microbial contents of some liquid preparations in Nigeria ${ }^{6}$. There is yet no report on the bioburden of tablets in large dispensing packages or containers which are common features in hospitals, clinics, pharmacies and patent medicine stores. This could be because of the under estimation of the health hazards to which patients are exposed, through the microbial contamination of such tablets dispensed from large packages.

The aim of this study is to investigate the incidence of microflora in tablets dispensed from large container packages and provide data on some of the tablet dosage forms commonly associated with those within the low socio-economic group of the society in Benin City, Nigeria. The implications for health and the central role for pharmacists in bringing pharmaceutical care to the populace would be highlighted.

\section{Materials and Methods}

\section{Media}

Nutrient broth, nutrient agar, MacConkey agar, Mannitol salt agar, Sabauraud Dextrose agar were all Oxoid products Oxoid, Basingstoke, UK).

\section{Preparation of tablet dispersion}

Ten (10) tablets each of ascorbic acid, chloroquine phosphate, paracetamol, folic acid (Emzor Pharmaceutical Industries Ltd. Lagos, Nigeria) and film coated ferrous sulphate (Eupharma Laboratories Ltd, Taluka, India) were randomly sampled from retail containers from five (5) community pharmacies in five different locations in Benin City. A similar procedure was adopted for the same drugs, from retail dispensing packs from five (5) public hospitals, also in different locations, within Benin metropolis.

Five (5) tablets each of ascorbic acid, chloroquine phosphate, ferrous sulphate and folic acid were dispersed in $10 \mathrm{ml}$ sterile normal saline; while five (5) tablets of paracetamol were dispersed in $20 \mathrm{ml}$ sterile 
normal saline. Similar procedure, as above were repeated for samples taken from unopened fresh containers from both retail pharmacy outlets and public hospital pharmacies. Tablet dispersions were mixed in a vortex mixer for 5 minutes to dislodge possible microbial cells. The solid particles sedimented out and the supernatant were used.

Determination of microbiological quality of tablets

One millilitre aliquot of each tablet dispersion was spread on nutrient agar plates, MacConkey agar plates, mannitol salt agar plates and Sabauraud dextrose agar plates, (in duplicates). The Sabauraud agar plates were incubated at ambient temperature of $25^{\circ} \mathrm{C}-27^{\circ} \mathrm{C}$, for $72-96 \mathrm{~h}$ while the other agar plates were incubated at $37^{\circ} \mathrm{C}$ for $48 \mathrm{~h}$ before they were observed for growth. The aerobic bacteria growth were subjected to further identification using the protocol of Cowan and Steel. ${ }^{7}$ The fungal growth were identified both microscopically and through the aid of an Atlas of mycology ${ }^{8}$.

The total viable aerobic bacterial count (dry surface plate count method) and the total viable count for moulds (dry surface plate count method) as well as the absence (or presence) of Escherichia coli and Staphylococcus aureus were assessed as earlier reported ${ }^{9,10}$.

\section{Results and Discussions}

The results of the microbiological examinations of tablets dispensed from large containers in hospitals and community pharmacies are shown in Tables 1 and 2, respectively. Our result showed that all the tablets had growth of both aerobic bacteria, Staphylococci and fungi. The aerobic organisms were mainly Bacillus species and Streptococci. The frequent occurrence of enterobacteriaceae among ascorbic acid and folic tablets from hospital and community pharmacies was curiously observed. We also observed the incidence of Staphylococci species, most especially among ascorbic acid and folic acid tablets. Some Gram-positive spore-formers were observed with some of the tablets. Among the fungi encountered with the tablets were Microsprum spp, Penicillium spp, Trichophyton, Aspergillus, Cephalosporium and Epidermophyton. The aerobic mesophilic bacteria and fungi were however within the standard numerical limits for non-sterile oral preparations like tablets ${ }^{2}$.

Spoilage of medicines involved basically, initial or early pioneer invaders of biodegrading microorganisms, which prepare the way for later invaders, by degrading complex nutrients, altering the surrounding $\mathrm{pH}$ and making more moisture available ${ }^{3}$. The microbiological quality, at the moment of administration of non-sterile pharmaceutical dosage forms like tablets, is dependent on the bioburden of the raw materials, both active drug and excipient ${ }^{11,12}$, hence the desirability of observing strictly contamination reduction, strategy at every stage of production. In an earlier study, aqueous preparations such as magnesium trisilicate mixture and kaolin and morphine mixture, were found to be highly contaminated $^{6}$; an observation that has serious health implications for the consuming public. Tablets and capsules constitute a large proportion of the medicines which are dispensed in modern dispensaries. Though many are now presented in blister packs, situations in most developing countries like Nigeria still present instances where such drugs are supplied in bulk packs and the prescribed amount counted from them. Mishandling of these drugs in the hands of untrained personnel could result in serious health hazards following ingestion of highly contaminated drugs by patients whose immunity is already compromised by illness. It was observed in this study, that most of the community pharmacies have largely untrained dispensers, hence the dispensary benches, spoons, trays are untidily kept. This practice coupled with the high level of unhygienic disposition could have explained the high 
JO Akerele \& GC Ukoh

Table 1: Microbial content of tablets from hospitals

Values in parenthesis represent counts obtained from unopened control packs

\begin{tabular}{|c|c|c|c|c|c|}
\hline & $\begin{array}{c}\text { ORIGIN } \\
\text { (HOSPITAL) }\end{array}$ & $\begin{array}{l}\text { Total viable } \\
\text { aerobic count } \\
\text { (cfu/g) }\end{array}$ & $\begin{array}{l}\text { Total viable } \\
\text { count for fungi } \\
\text { (cfu/g) }\end{array}$ & $\begin{array}{l}\text { Enterobacteriaceae } \\
\quad(\mathrm{cfu} / \mathrm{g})\end{array}$ & $\begin{array}{l}\text { Staph aureus } \\
\text { (cfu/g) }\end{array}$ \\
\hline \multirow[t]{5}{*}{ A } & Ascorbic acid & $67(15)$ & $5(4)$ & $5(0)$ & $40(2)$ \\
\hline & Chloroquine & $8(2)$ & 9 (2) & $0(0)$ & $0(0)$ \\
\hline & Ferrous (salts) & $9(2)$ & $4(1)$ & $0(0)$ & $0(0)$ \\
\hline & Folic acid & $10(3)$ & 3 (2) & $0(0)$ & $0(0)$ \\
\hline & Paracetamol & $5(2)$ & 7 (2) & $0(0)$ & $0(0)$ \\
\hline \multirow[t]{5}{*}{$B$} & Ascorbic acid & $5(3)$ & $3(1)$ & $5(0)$ & $11(1)$ \\
\hline & Chloroquine & $3(2)$ & $5(2)$ & $0(0)$ & $0(0)^{\prime}$ \\
\hline & Ferrous (salts) & $7(2)$ & $9(1)$ & $0(0)$ & $0(0)$ \\
\hline & Folic acid & $3(1)$ & $10(1)$ & $0(0)$ & $0(0)$ \\
\hline & Paracetamol & $8(3)$ & $4(2)$ & $7(0)$ & $0(0)$ \\
\hline \multirow[t]{5}{*}{ C } & Ascorbic acid & $9(2)$ & $3(2)$ & $5(0)$ & $4(2)$ \\
\hline & Chloroquine & $4(1)$ & $5(1)$ & $7(0)$ & $0(0)$ \\
\hline & Ferrous (salts) & $3(2)$ & $7(2)$ & $0(0)$ & $0(0)$ \\
\hline & Folic acid & $1.0 \times 10^{2}(3)$ & $9(1)$ & $4(0)$ & $8(1)$ \\
\hline & Paracetamol & $5(0)$ & $5(2)$ & $6(0)$ & $0(0)$ \\
\hline \multirow[t]{5}{*}{ D } & Ascorbic acid & $72(5)$ & $0(1)$ & $8(0)$ & $3(2)$ \\
\hline & Chloroquine & $5(3)$ & $3(2)$ & $0(0)$ & $0(0)$ \\
\hline & Ferrous (salts) & $3(2)$ & $3(3)$ & $0(0)$ & $0(0)$ \\
\hline & Folic acid & $5(1)$ & $8(1)$ & $4(0)$ & $5(2)$ \\
\hline & Paracetamol & $9(2)$ & $9(2)$ & $0(0)$ & $0(0)$ \\
\hline \multirow[t]{5}{*}{$\mathrm{E}$} & Ascorbic acid & $3(2)$ & $8(3)$ & $7(0)$ & $7(1)$ \\
\hline & Chloroquine & $9(1)$ & $3(1)$ & $0(0)$ & $0(0)$ \\
\hline & Ferrous (salts) & $5(1)$ & $8(2)$ & $0(0)$ & $5(2)$ \\
\hline & Folic acid & 7 (2) & $8(1)$ & $3(0)$ & $8(1)$ \\
\hline & Paracetamol & $4(2)$ & $5(1)$ & $0(0)$ & $6(1)$ \\
\hline
\end{tabular}

incidence of Enterobacteriaceae and Staphylococci species isolated from ascorbic acid and folic acid tablets from community pharmacies.

It was also observed that tablets from public hospitals appeared to have lower incidence of microbial contamination, particularly with respect to Enterobacteriaceae and Staphylococci species. This could be due to less than casual attention to personal hygiene on the part of dispensers in community pharmacies, compared with public hospitals. The expected higher turnover, and hence less exposure of opened containers, in hospital settings, could also explain the lower incidence of Enterobacteriaceae and Staphylococcispecies, in public hospitals. It is pertinent to point out that, in addition to microbial degradation and spoilage, tablets like aspirin or penicillins, could cause lifethreatening reactions, when allergic persons are exposed to very small particles from mishandling. It is for these additional reasons that pharmacists must emphasize to dispensers, strict observance for accurate tablet counting with devices, properly cleaned, before and after use.

Personnel who handle drugs generally and exposed tablets, in particular, must wear properly laundered overalls, gloves, face 
JO Akerele \& GC Ukoh

Table 2: Microbial content of tablets from community pharmacies

Values in parenthesis represent counts obtained from unopened control packs

\begin{tabular}{|c|c|c|c|c|c|}
\hline \multicolumn{2}{|c|}{ ORIGIN (PHARMACY) } & $\begin{array}{c}\begin{array}{c}\text { Total Viable } \\
\text { aerobic count } \\
(\mathrm{cfu} / \mathrm{g})\end{array} \\
2.5 \times 10^{2}(12)\end{array}$ & $\begin{array}{c}\text { Total viable } \\
\text { count for fungi } \\
\text { (cfu/g) }\end{array}$ & $\begin{array}{c}\begin{array}{c}\text { Enterobacteriaceae } \\
(\mathrm{cfu} / \mathrm{g})\end{array} \\
10(0)\end{array}$ & $\begin{array}{c}\begin{array}{c}\text { Staph aurel } \\
\text { (cfu/g) }\end{array} \\
0(0)\end{array}$ \\
\hline Q & $\begin{array}{l}\text { Ascorbic acid } \\
\text { Chloroquine } \\
\text { Ferrous (salts) } \\
\text { Folic acid } \\
\text { Paracetamol }\end{array}$ & $\begin{array}{c}2.5 \times 10^{2}(12) \\
5(2) \\
3(1) \\
2.5 \times 10^{2}(4) \\
7(2)\end{array}$ & $\begin{array}{c}1.5 \times 10^{2}(3) \\
6(1) \\
5(1) \\
3(0) \\
9(0)\end{array}$ & $\begin{array}{c}10(0) \\
0(0) \\
0(0) \\
10(0) \\
0(0)\end{array}$ & $\begin{array}{l}0(0) \\
0(0) \\
0(0) \\
2(0) \\
5(0)\end{array}$ \\
\hline $\mathrm{R}$ & $\begin{array}{l}\text { Ascorbic acid } \\
\text { Chloroquine } \\
\text { Ferrous (salts) } \\
\text { Folic acid } \\
\text { Paracetamol }\end{array}$ & $\begin{array}{c}1.0 \times 10^{2}(4) \\
10(1) \\
7(1) \\
1.0 \times 10^{1}(2) \\
5(0)\end{array}$ & $\begin{array}{l}7(0) \\
5(0) \\
3(0) \\
9(1) \\
2(1)\end{array}$ & $\begin{array}{l}0(0) \\
0(0) \\
0(0) \\
0(0) \\
2(0)\end{array}$ & $\begin{array}{c}1 \times 10^{2}(2) \\
0(0) \\
1 \times 10^{2}(2) \\
3(0) \\
7(1)\end{array}$ \\
\hline$x$ & $\begin{array}{l}\text { Ascorbic acid } \\
\text { Chloroquine } \\
\text { Ferrous (salts) } \\
\text { Folic acid } \\
\text { Paracetamol }\end{array}$ & $\begin{array}{c}1.0 \times 10^{2} \\
3(1) \\
7(2) \\
10(1) \\
5(0)\end{array}$ & $\begin{array}{l}10(1) \\
7(0) \\
5(0) \\
3(0) \\
9(0)\end{array}$ & $\begin{array}{l}7(0) \\
0(0) \\
0(0) \\
0(0) \\
0(0)\end{array}$ & $\begin{array}{l}8(1) \\
5(1) \\
3(2) \\
5(2) \\
0(0)\end{array}$ \\
\hline $\mathrm{Y}$ & $\begin{array}{l}\text { Ascorbic acid } \\
\text { Chloroquine } \\
\text { Ferrous (salts) } \\
\text { Folic acid } \\
\text { Paracetamol }\end{array}$ & $\begin{array}{l}1.0 \times 10^{2} \\
6(0) \\
3(1) \\
9(0) \\
3(1)\end{array}$ & $\begin{array}{l}9(0) \\
5(2) \\
5(3) \\
3(3) \\
7(0)\end{array}$ & $\begin{array}{l}8(3) \\
0(0) \\
0(0) \\
4(0) \\
6(0)\end{array}$ & $\begin{array}{l}8(1) \\
3(1) \\
0(0) \\
9(2) \\
0(0)\end{array}$ \\
\hline Z & $\begin{array}{l}\text { Ascorbic acid } \\
\text { Chloroquine } \\
\text { Ferrous (salts) } \\
\text { Folic acid } \\
\text { Paracetamol }\end{array}$ & $\begin{array}{c}7(0) \\
3(0) \\
9(0) \\
10(2) \\
5(0)\end{array}$ & $\begin{array}{l}5(1) \\
3(0) \\
3(0) \\
5(0) \\
3(0)\end{array}$ & $\begin{array}{l}0(0) \\
0(0) \\
0(0) \\
5(0) \\
0(0)\end{array}$ & $\begin{array}{l}6(1) \\
0(0) \\
9(1) \\
3(2) \\
0(0)\end{array}$ \\
\hline
\end{tabular}

masks, to exclude excessive droplets from nasal passage and buccal cavity, that are generally associated with sneezing, coughing or talking. Hand washing facilities must in addition be available and usable. Above all, more cheaply designed multi-dose packs which dispense tablets individually through a shutter release aperture, without having to open the container cover would ultimately revolutionize large package dispensing.

The study has highlighted the microbial contamination level of tablets dispensed from retail packs from both public and community pharmacies. Ascorbic acid and folic acid tablets mainly from community pharmacies were contaminated with Staphylococci spps and Enterobacteriaceae, which are included in the exclusive criteria for non-sterile oral formulations. Strict observance of dispensing guidelines would reduce the bioburden of retain dispensing and the associated health hazards.

\section{Acknowledgements}

Authors acknowledge the technical assistance of Messrs Anthony Okeke and Ikenna Ozumba of the Faculty of Pharmacy, University of Benin, Benin City Nigeria for some aspects of this work. 


\section{JO Akerele \& GC Ukoh}

\section{References}

1. Kallings, L.O., Silver Stolpe, L. and Ernerfeldt, F. Microbiological contamination of medical preparations. Act. Pharm. Suec. 1966; 3: 219 $-228$.

2. Parker, M.S. Microbiological contamination and preservation of pharmaceutical preparations. In: Aulton, ME (Ed). Pharmaceutics: The science of dosage from design. Churchill Livingstone, China, 2000; pp. $479-508$.

3. Parker, M.S. The preservation of oral dosage forms. Int. J. Pharm. Tech. Prod. Mfr. 1984; 5: 20 24.

4. Grimm, W. Stability testing in industry for worldwide marketing. Drug Dev. Ind. Pharm. 1986; 12: $1259-1292$.

5. Blair, T.C. Buckton, G. and Bloon field, S.F. Preservation of solid oral dosage forms. In Bloomfield, S.F. Baird, R. Leak, R.E. and Leech. R (Eds) Microbial Quality Assurance in Pharmaceuticals, Cosmetics and Toiletries. Ellis Horwood Ltd, Chischester 1988: pp. 104 118.

6. Onawunmi, G.O. Microbial contamination of oral and topical pharmaceuticals manufactured in
Nigeria. West. Afr. J. Pharm. 1999; 13(3); 58 63.

7. Cowan, ST and Steel, K.J. Manual for the Identification of Medical Bacteria, $2^{\text {nd }}$ Edn. Cambridge, Cambridge University Press, 1984.

8. Rohde, B. and Hartmann G. Introducing myocolgy by examples. Schering Aktiengesellschaft, 1980.

9. Van Doorne, $H$. and Claushauis, EPM. The quantitative determination of Enterobacteriaceae in pharmaceutical preparations. Int. J. Pharm. 1979; 4: 119-125.

10. Waterman, RF, Sumner, ED, Baldwin, JN and Warren, FW. Survival of Staphylococcus aureus on pharmaceutical oral solid dosage forms. J. Pharm. Sci. 1973; 62: 1317 - 1320.

11. Devleeschovwer, MJ and Dony, J. Flore. Microbienne des medicaments donnèes çcologiques et sensibilité aux antibiotiques (Ire partie: formes magistiale seches). J. Pharm. Belg. 1979; 34: $189-203$.

12. Khante, S., Nikore, R.L., and Joshi, S.B. Microbial contamination studies in sterile and non-sterile pharmaceutical formulations in consumers' storage conditions Ind. J. Hosp. Pharm. 1979; 1: $114-117$ 